\title{
Sea lice in Iceland: assessing the status and current implications for aquaculture and wild salmonids
}

\author{
Chelsey M. Karbowski ${ }^{1, *}$, Bengt Finstad ${ }^{2}$, Niklas Karbowski ${ }^{1}$, Richard D. Hedger ${ }^{2}$ \\ 128 Georgian Crt, Dartmouth, Nova Scotia Canada, B2W 6E7, Canada \\ ${ }^{2}$ Norwegian Institute for Nature Research, PO Box 5685 Torgarden, 7485 Trondheim, Norway
}

\begin{abstract}
This is the first in-depth study which quantifies lice infestation levels on wild and farmed salmonids in a fjord system in Iceland (Arnarfjörður, Westfjords) and gives a baseline for the assessment of sea lice infestation within Icelandic fjords. The prevalence, abundances and intensities of sea lice infestation observed in this study were low and below the estimated thresholds for negative impacts of sea lice on their hosts. However, greater infestation levels occurred in 2 study sites located close to aquaculture farms, suggesting that farms were contributing to sea lice infestation. We infer that if production were to remain at the level in operation during this study, the threat of sea lice epidemics will be low. However, if salmonid aquaculture develops and production is expanded within the fjord, the risk of sea lice epidemics will increase, raising the need for environmental monitoring and coastal zone management.
\end{abstract}

KEY WORDS: Iceland $\cdot$ Aquaculture $\cdot$ Sea lice $\cdot$ Salmonids $\cdot$ Interactions $\cdot$ Management

\section{INTRODUCTION}

Three native species of salmonid exist in Iceland: Atlantic salmon Salmo salar, brown trout Salmo trutta and Arctic charr Salvelinus alpinus. These species are found in various locations throughout Iceland, with most populations originating from the southern coast (Klemetsen et al. 2003). Relatively few populations exist in the Westfjords, in the northwestern region of the country. However, small populations are still observed here and are considered of particular importance for the present study as aquaculture production of salmonids has increased here in recent years.

All 3 species of salmonid are farmed in Iceland, with the first trial sea-cage farm having been opened in 1972 in Hvalfjorður, on the western coast of Iceland (Kristinsson 1992). The aquaculture industry was challenged by the economic crash of 2007/2008, when total aquaculture production dropped by almost $50 \%$ (Rosten 2013). At the end of 2010, there were over 68 registered aquaculture farms, with only

${ }^{*}$ Corresponding author: chelsey.m.landry@gmail.com
10 sea-cage farms, the majority producing cod Gadus morhua (Rosten 2013). Since the mid-2010s, the popularity of salmonid aquaculture has overtaken that of cod aquaculture as the former is more viable due to fast turnaround times and greater global marketability.

Historically, concerns related to sea-cage farming in Iceland were associated with foreign exchange, damage of cages from storms and the impact of jellyfish on the farms (Paisley et al. 2010). Today, with the increased production of sea-cage farmed Atlantic salmon, new concerns have developed. The first concern relates to the impact on the environment and includes the effects of sediment deposition, nutrient load increases and impacts on native species. The second and most paramount concern relates to the effect of sea lice parasites, primarily of 2 specific species: Caligus elongatus (von Nordmann 1832) and Lepeophtheirus salmonis (Krøyer, 1837) (Pike \& Wadsworth 2000).

Sea lice are a serious threat to wild salmonids and salmonid farming in the northern hemisphere (Costello 1993, 2006, Pike \& Wadsworth 2000, Brooker et

() The authors 2019. Open Access under Creative Commons by Attribution Licence. Use, distribution and reproduction are unrestricted. Authors and original publication must be credited. 
al. 2018, Thorstad \& Finstad 2018). For decades, research has been evaluating the effects of sea lice infestation on both wild and farmed salmonids. It is now well known that sea lice infestation and associated attachment and feeding on the host can affect host growth, fecundity and survival (Pike \& Wadsworth 2000, Boxaspen 2006, Costello 2006, Finstad \& Bjørn 2011, Finstad et al. 2011, Skilbrei et al. 2013).

Although sea lice are naturally occurring, they were not regarded as a serious issue until the development and expansion of aquaculture. Research today focuses on the infestation of sea lice on salmonid farms and the interaction of sea lice between wild and farmed salmonids. Today, the largest sources of sea lice in the coastal ocean can be traced to areas with sea-cage aquaculture farms (Butler et al. 2003, Costello 2009a, Serra-Llinares et al. 2014, 2016, Gargan et al. 2016, Thorstad \& Finstad 2018) due to the continuous supply of hosts sustaining the sea lice population year-round (Johnsen et al. 2014).

Iceland has a unique opportunity for providing data not only for its own aquaculture and wild fishery sector but also for those of other countries. While countries like Norway, Ireland and Scotland can only react to the problem of sea lice epizootics, with nearly no historical data from before the start of intensive fish farming, the situation is different in Iceland. Salmonid aquaculture in Iceland in general, and in the Westfjords specifically, is a young industry, with farms in the Westfjords operating with salmon for only 3 to 5 yr. Data that are collected prior to major development can substantially improve the management and control of sea lice, demonstrating the natural infestation rates and abundances on wild fish.

Our research study sought to evaluate the prevalence, abundance and intensity of sea lice infestation within the Icelandic fjord system of Arnarfjörður, located in the Westfjords region of Iceland. The aim of the study was to collect data on sea lice infestation from locations with a range of distances to the existing salmon farms to determine (1) if there was already an impact from salmon aquaculture on infestation levels in wild stocks and (2) the prevalence and intensity of sea lice and the distribution of life cycle stages on infested hosts within the fjord. Two methods of sampling were used: gill netting and sentinel cages (Bjørn et al. 2001).

\section{MATERIALS AND METHODS}

The study was conducted in the Arnarfjörour fjord system $\left(65^{\circ} 45^{\prime} \mathrm{N}, 23^{\circ} 40^{\prime} \mathrm{W}\right)$, the second-largest fjord system located in the northern Westfjords region of Iceland (Fig. 1). This is a deep glacial fjord system, $\sim 30 \mathrm{~km}$ long, $10 \mathrm{~km}$ wide at its widest point, with steep drop-offs extending to 90-110 m before a shallow sill at $\sim 60 \mathrm{~m}$ depth (Johnsen \& Tveranger 2011). The system comprises 3 parts: (1) the outer basin (Arnarfjörður), (2) the eastern basin (Borgarfjörður) and (3) the southern basin (Suðurfirðir). There is no substantial influence from freshwater inputs into the fjord, with only minor river outflow. The currents in the area are variable both in time and space with velocities ranging from an average of $4.2 \mathrm{~cm} \mathrm{~s}^{-1}$ to a maximum of $21.5 \mathrm{~cm} \mathrm{~s}^{-1}$ at $15 \mathrm{~m}$ depth (Johnsen \& Tveranger 2011). Despite large spatial and temporal variability, the currents are dominantly directed towards the north, where the east-west component of the current oscillates with the tides (Johnsen \& Tveranger 2011). The fjord has a tidal amplitude of approximately 3 to $3.5 \mathrm{~m}$ in the outer region, with tidal water flushing into the fjord twice daily, and an exchange rate of $<2 \mathrm{wk}$ for the surface water volume above the fjord sill. Due to the lack of a major freshwater source, the strong circulation and topography,

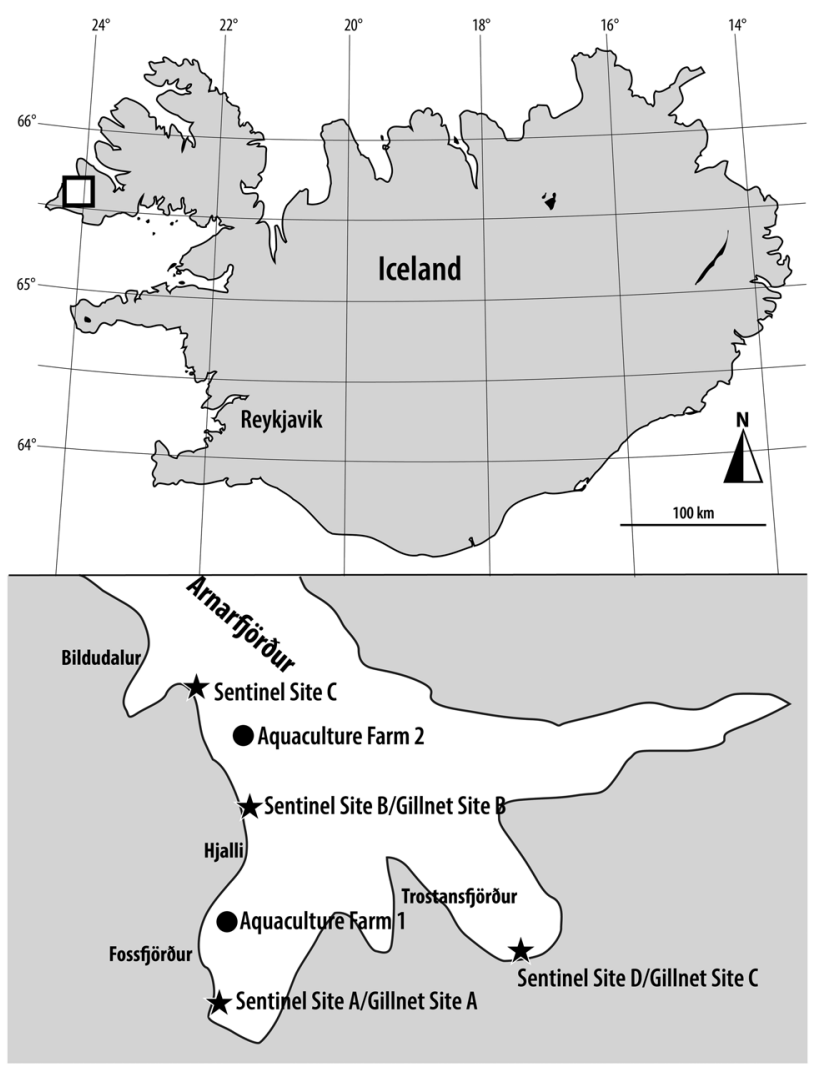

Fig. 1. Location of study sites (gillnet and sentinel cage study) and the 2 aquaculture farms in Arnarfjördur $\left(65^{\circ} 45^{\prime} \mathrm{N}, 23^{\circ} 40^{\prime} \mathrm{W}\right)$ in the northern Westfjords region of Iceland 
the water is well mixed in the vertical dimension (Johnsen \& Tveranger 2011). The fjord is used for various activities, such as wild calcified seaweed extraction, recreational salmon fishing and fish farming. Study sites were chosen within the fjord system based on the low-scale Atlantic salmon aquaculture at the time (2 farms of low volume-1500 and 3500 tonnes, $\sim 6 \mathrm{~km}$ distant from one another) as well as the presence of wild salmonid populations.

The study was conducted in July (Gillnet Sites A, B, $C_{i}$ Sentinel cage Sites A, B, C, D), August (Gillnet Sites A, B, C; Sentinel cage Sites A, B, C, D) and September 2014 (Sentinel cage Sites A, B, C, D) (Fig. 1) for as many days as was technically possible, ranging from 15 to $20 \mathrm{~d}$. The timeframe was chosen because it matched the stage when anadromous fish could be found in the waters off the coast and thus be sampled using the gillnetting method, as well as having weather conditions optimal for field research during these months, allowing sampling to have the highest likelihood of success. This provided a period with both the highest chance of smolt survival and the highest chance of fish encountering sea lice in the water column.

\subsection{Gillnet sampling}

For gillnet sampling, 3 study sites were selected: 1 located near each farm and 1 located $8.5 \mathrm{~km}$ away from both farms. Site A was located in the more inland part of Fossfjörður, $0.5 \mathrm{~km}$ from Farm 1. Site B was in close proximity to Farm 2. Site C was located in Trostansfjörður, $\sim 8.5 \mathrm{~km}$ from both farms (Fig. 1). Sampling was based on methods used to assess sea lice on wild salmonids (Bjørn et al. 2001).

Gillnets were $25 \mathrm{~m}$ long and $2 \mathrm{~m}$ deep, with upper floats and lower weights. Two mesh sizes were used: 21 and $26 \mathrm{~mm}$. Four to 6 nets were placed at one site at a time. The nets were placed along the coast $2-3 \mathrm{~h}$ before high tide and checked continuously while they remained in the water for a period of $\sim 4$ to $6 \mathrm{~h}$, corresponding to roughly 1.5 to $2 \mathrm{~h}$ before low tide, until they were removed. When daylight and weather permitted, sampling was continued throughout another tidal cycle, and the nets were left at sea for at least $12 \mathrm{~h}$, continuously monitored over this time. For each site, the desired sample size was 25 to 30 fish per month, but this was not always reached due to poor weather and low catchability at times. In these cases, the minimum fish sample size was set to 20 fish site ${ }^{-1} \mathrm{mo}^{-1}$.
Sampling focused on 1 site $\mathrm{d}^{-1}$ over the course of the month. During the 6 to $12 \mathrm{~h}$ window that the gillnets were in place and monitored, fish were removed from the net immediately after being detected and placed in bags labelled with the gillnet number, site and date. The fish were then placed in a cooler and examined upon returning to the lab that same day. Data collected included gillnet number, site, date, species, length, and weight of the fish, and the number, species (Lepeophtheirus salmonis or Caligus elongatus) and sex/life stage (chalimus 1 to 4 , preadult 1 female, preadult 2 female, preadult 1 male; preadult 2 male, adult male, or adult female) of any sea lice on the fish.

\subsection{Sentinal cage study}

For the sentinel cage study, 4 sites were selected. Site A was located in Fossfjörour in the southernmost fjord of the Suðurfirðir branch; this is in the inner fjord, $\sim 6 \mathrm{~km}$ from Farm 2 and $1.5 \mathrm{~km}$ from Farm 1. Site B was located in Otradalur, near Hjalli, in the southernmost fjord of the Suðurfirðir branch; this is the middle fjord region, $1 \mathrm{~km}$ parallel to Farm 2 and $3.0 \mathrm{~km}$ from Farm 1. Site C was located in Bildudalur along the southern coast of Arnarfjörður near the outer part of the fjord midway to open sea; this is in the outer fjord, located up-current from the 2 farms, $3.5 \mathrm{~km}$ from Farm 2 and $7.5 \mathrm{~km}$ from Farm 1. Site D was located in Trostansfjörour in the more northern section of the Suðurfirðir branch; this site is $\sim 8.5 \mathrm{~km}$ from both Farm 1 and Farm 2 (Fig. 1). Sentinel cage sampling used was based on a modification of Bjørn et al. (2011).

Four sentinel cages were placed at each site at the beginning of each month from July to September and remained at sea for $\sim 21 \mathrm{~d}$. Following the first placement, 2 minor adjustments were made to the sentinel cages: a heavier weight was fixed under the bottom of the cage and holes were drilled in the bottom ring to make them more stable in the water and reduce fish mortality. Each cage was supplied monthly with 27 salmon smolts. After $\sim 21 \mathrm{~d}$, smolts were removed individually using a hand net with a $3 \mathrm{~mm}$ mesh size, immediately euthanized by a blow to the head, placed individually in $10 \mathrm{l}$ plastic bags that were labelled with the cage number, site number and date, which were then placed in a cooler and brought back to a laboratory for inspection. If multiple sites were collected in one day which could not all be analyzed immediately, fish from one site were placed in a freezer for analysis the following day: frozen 
fish were removed from the freezer on the day of analysis and thawed for $\sim 2 \mathrm{~h}$. Fish length and weight were measured, damage from sea lice was inspected, and the numbers of sea lice of the different species (L. salmonis and C. elongatus) and life stage were calculated. Sea lice were identified visually based on specific characteristics displayed in the EWOS sea lice identification key and developed in the 1998 National Strategy for Sea Lice Control (www.mattilsynet.no) and on characteristics identified in the literature (Schram 1993, 2004, Piasecki \& MacKinnon 1995, Hamre et al. 2013). Additionally, the number of smolt mortalities were recorded for each cage per site and all sites.

\subsection{Other data and analysis}

Sea temperature and salinity were measured at the 4 sentinel cage study sites within the fjord at depths of $0.1,1,2,3,4$ and $5 \mathrm{~m}$ once on 24 October using a temperature and conductivity meter (Profile Line Cond 3110, WTW/Xylem). Using an equivalent instrument, temperature was also measured at Farm 1 at a depth of $7 \mathrm{~m}$. Measurements were conducted daily beginning in May 2014 and were continued throughout the study period.

Data on salmon smolt biomass within each farm was provided by the companies operating the farms. Sea lice data from the 2 farms were also collected by the farm operators, based on Icelandic monitoring requirements (1 measurement $\mathrm{mo}^{-1}$, first implemented in the year of the study; Jón Örn Pálsson pers. comm.). Operators at both farms sampled $\sim 25$ salmonids concurrently with the collection of sea lice data. Farm 1 was sampled for 2 mo: August and September; Farm 2 was sampled for 4 mo: July, August, September and October.

Lice counts from the gillnets and sentinel cages were used to determine infestation rates, quantified as prevalence (the proportion of infested fish), abundance (the mean number of lice per fish for all fish, infected and uninfected) and intensity (the mean number of lice per infested fish) following Bush et al. (1997) for each site and date. For the gillnet data, Kruskal-Wallis tests were performed, following the approach of similar studies (Bjørn et al. 2007, 2011) to test for differences in abundance among the 3 sites per month. To test for possible effects of fish size on infestation, fish were pooled into 2 size classes (body length $<25 \mathrm{~cm}$ and body length $\geq 25 \mathrm{~cm}$ ); differences in abundance among sites were examined according to size class using Kruskal-Wallis tests, and differ- ences in total lice abundance per size class were examined using Wilcoxon tests. For the sentinel cage data, Wilcoxon tests were used to determine if there were differences in lice abundance according to month, and Kruskal-Wallis tests were used to determine if there was a difference in lice abundance between sites for each month.

\section{RESULTS}

\subsection{Gillnet sampling}

Of the 160 fish caught in July and August, 155 were sea trout, 3 were Atlantic salmon, 1 was Pacific salmon Onchorynchus gorbuscha and 1 was Arctic charr. Sea trout body size was similar regardless of month of capture: July, mean body length $=24.3 \mathrm{~cm}$ (range $=16.7-55.6 \mathrm{~cm}, \mathrm{~N}=76$ ); August, mean body length $=24.4 \mathrm{~cm}$ (range $=18.2-42.2 \mathrm{~cm}, \mathrm{~N}=79) . \mathrm{A}$ total of 801 sea lice were counted on the 160 caught fish. In total, 67 of the sea lice could not be identified due to deformation, representing $12 \%$ of all sampled lice. The identified sea lice were either Lepeophtheirus salmonis or Caligus elongatus with total abundances of 634 and 100, respectively.

Prevalence, abundance and intensity increased from July to August at all 3 sites (Tables 1 \& 2). For all fish (regardless of size), prevalence ranged between 0.67 (Site A in July) and 1.0 (Site B in August), abundance ranged between 3.28 (Site A in July) and 7.52 (Site B in August), and intensity ranged between 4.18 (Site B in July) and 7.52 (Site B in August).

Table 1. Prevalence, abundance and intensity (mean \pm SD) for the month of July at all 3 sampling sites for the gillnet study. Prevalence: proportion of infested fish in the sample; abundance: mean number of lice per fish of all fish that were sampled; intensity: mean number of lice per infested fish that was sampled. Numbers of fish and values for all fish caught at the site as well as values for fish $<25 \mathrm{~cm}$ and $\geq 25 \mathrm{~cm}$ are included

\begin{tabular}{|c|c|c|c|c|c|}
\hline \multirow[t]{2}{*}{ Site } & \multicolumn{2}{|c|}{ Size group } & \multirow[t]{2}{*}{ Prev. } & \multirow[t]{2}{*}{ Abundance } & \multirow[t]{2}{*}{ Intensity } \\
\hline & Size (cm) & $\mathrm{N}$ & & & \\
\hline \multirow[t]{3}{*}{ A } & All & 18 & 0.67 & $3.28( \pm 4.60)$ & $4.92( \pm 4.89)$ \\
\hline & $<25$ & 10 & 0.62 & $3.62( \pm 1.90)$ & $5.80( \pm 2.41)$ \\
\hline & $\geq 25$ & 8 & 0.70 & $3.00( \pm 1.73)$ & $4.29( \pm 2.07)$ \\
\hline \multirow[t]{3}{*}{ B } & All & 24 & 0.96 & $4.00( \pm 3.22)$ & $4.18( \pm 3.17)$ \\
\hline & $<25$ & 22 & 1.00 & $1.00( \pm 1.00)$ & $1.00( \pm 1.00)$ \\
\hline & $\geq 25$ & 2 & 0.95 & $4.14( \pm 2.03)$ & $4.33( \pm 2.08)$ \\
\hline \multirow[t]{3}{*}{$\mathrm{C}$} & All & 36 & 0.78 & $3.89( \pm 4.54)$ & $5.00( \pm 4.58)$ \\
\hline & $<25$ & 23 & 0.69 & $2.54( \pm 1.59)$ & $3.67( \pm 1.91)$ \\
\hline & $\geq 25$ & 13 & 0.83 & $4.65( \pm 2.16)$ & $5.63( \pm 2.37)$ \\
\hline
\end{tabular}


Table 2. Prevalence, abundance and intensity (mean \pm SD) (see Table 1 for definitions) for the month of August at all 3 sampling sites for the gillnet study

\begin{tabular}{|cccccc|}
\hline \multirow{2}{*}{ Site } & \multicolumn{2}{c}{ Size group } & Prev. & Abundance & Intensity \\
& Size $(\mathrm{cm})$ & $\mathrm{N}$ & & & \\
\hline $\mathrm{A}$ & All & 28 & 0.86 & $4.57( \pm 3.75)$ & $5.33( \pm 3.50)$ \\
& $<25 \mathrm{~cm}$ & 15 & 0.77 & $4.69( \pm 2.17)$ & $6.10( \pm 2.47)$ \\
& $\geq 25 \mathrm{~cm}$ & 13 & 0.93 & $4.47( \pm 2.11)$ & $4.79( \pm 2.19)$ \\
$\mathrm{B}$ & All & 25 & 1.00 & $7.52( \pm 5.48)$ & $7.52( \pm 5.48)$ \\
& $<25 \mathrm{~cm}$ & 22 & 1.00 & $8.33( \pm 2.89)$ & $8.33( \pm 2.89)$ \\
& $\geq 25 \mathrm{~cm}$ & 3 & 1.00 & $7.41( \pm 2.72)$ & $7.41( \pm 2.72)$ \\
$\mathrm{C}$ & All & 29 & 0.97 & $6.66( \pm 5.82)$ & $6.89( \pm 5.78)$ \\
& $<25 \mathrm{~cm}$ & 21 & 0.88 & $8.62( \pm 2.94)$ & $9.86( \pm 3.14)$ \\
& $\geq 25 \mathrm{~cm}$ & 8 & 1.00 & $5.90( \pm 2.43)$ & $5.90( \pm 2.43)$ \\
& & & & & \\
\hline
\end{tabular}

At Site A in July, nearly $80 \%$ of all lice were sessile, whereas the 2 other sites had sessile lice frequencies of $<10 \%$, with Site C fish having no sessile lice (Fig. 2). At all 3 sites, fish had a greater number of adult lice in August compared to July, although the amount of increase varied according to site. Fish at Site A had the highest number of adult lice in August (>80\%), whereas fish at Site B and C had frequencies $>60 \%$.

The proportional composition of developmental lice stages varied according to site and month for both L. salmonis (Fig. 3) and C. elongatus (Fig. 4). The dominant life cycle stages for $L$. salmonis found on fish sampled in July were chalimus 2 at Site A, preadult 2 female and adult male for Site B, and preadult 2 female and adult male and female for Site C. For L. salmonis found on fish sampled in August, adult male and female were on average the dominant stages, with preadult 1 and 2 female having slightly lower averages. C. elongatus showed a lower mean number in general for samples from both months and all 3 sites. For fish caught in July, at both Site A and B, only chalimus 3 and 4 as well as adult male lice were recorded on the fish,

Fig. 3. Mean \pm SD abundance (see Table 1) of Lepeophtheirus salmonis from the gillnet study. Data are visualized separately for all 3 sampling sites and both sampling months. $\mathrm{CH} 1$ : chalimus 1; $\mathrm{CH} 2$ : chalimus 2; P1F: preadult 1 female; P2F: preadult 2 female; P1M: preadult 1 male; P2M: preadult 2 male; ADM: adult male; ADF: adult female
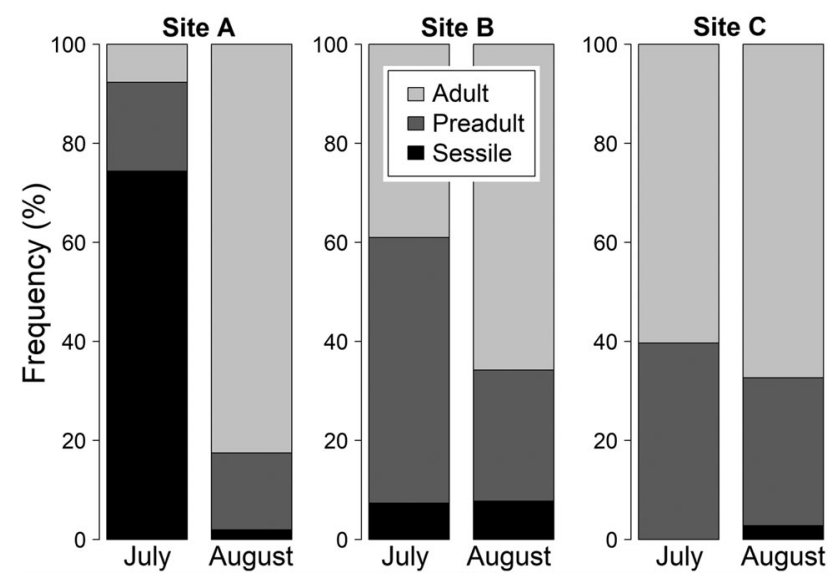

Fig. 2. Frequencies of sessile, preadult and adult lice shown in percent of the total sea lice population from the gillnet study. Data is visualized separately for each sampling site and the 2 sampling months

while fish caught at Site C were carrying chalimus 4 and both adult male and female $C$. elongatus. The dominant stage on fish caught at all sites in August was adult female, with the only other stages found being chalimus 4 at Site A and adult male at Site B and C.
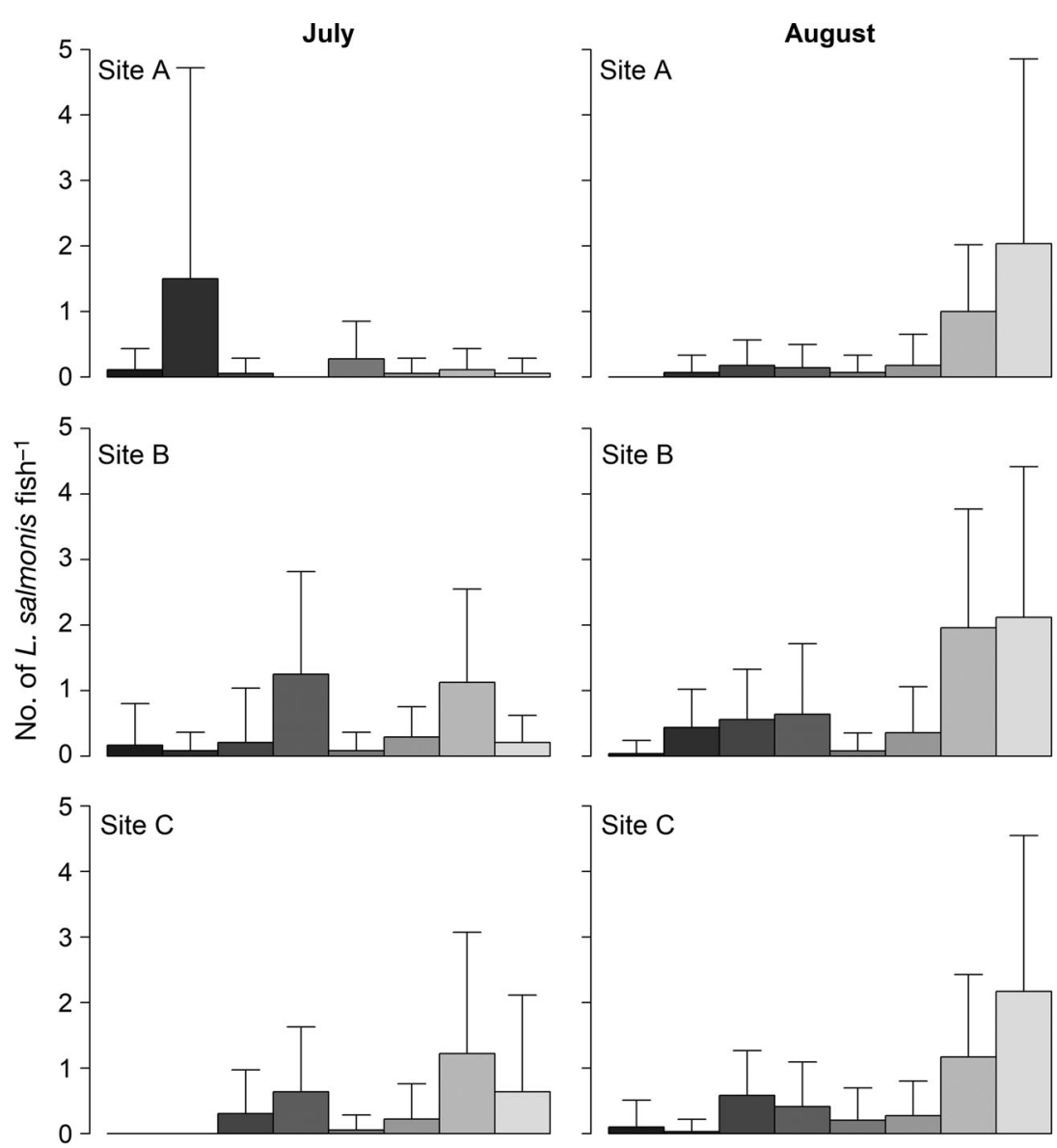

$\mathrm{CH} 1 \mathrm{CH} 2$ P1F P2F P1M P2M ADM ADF 

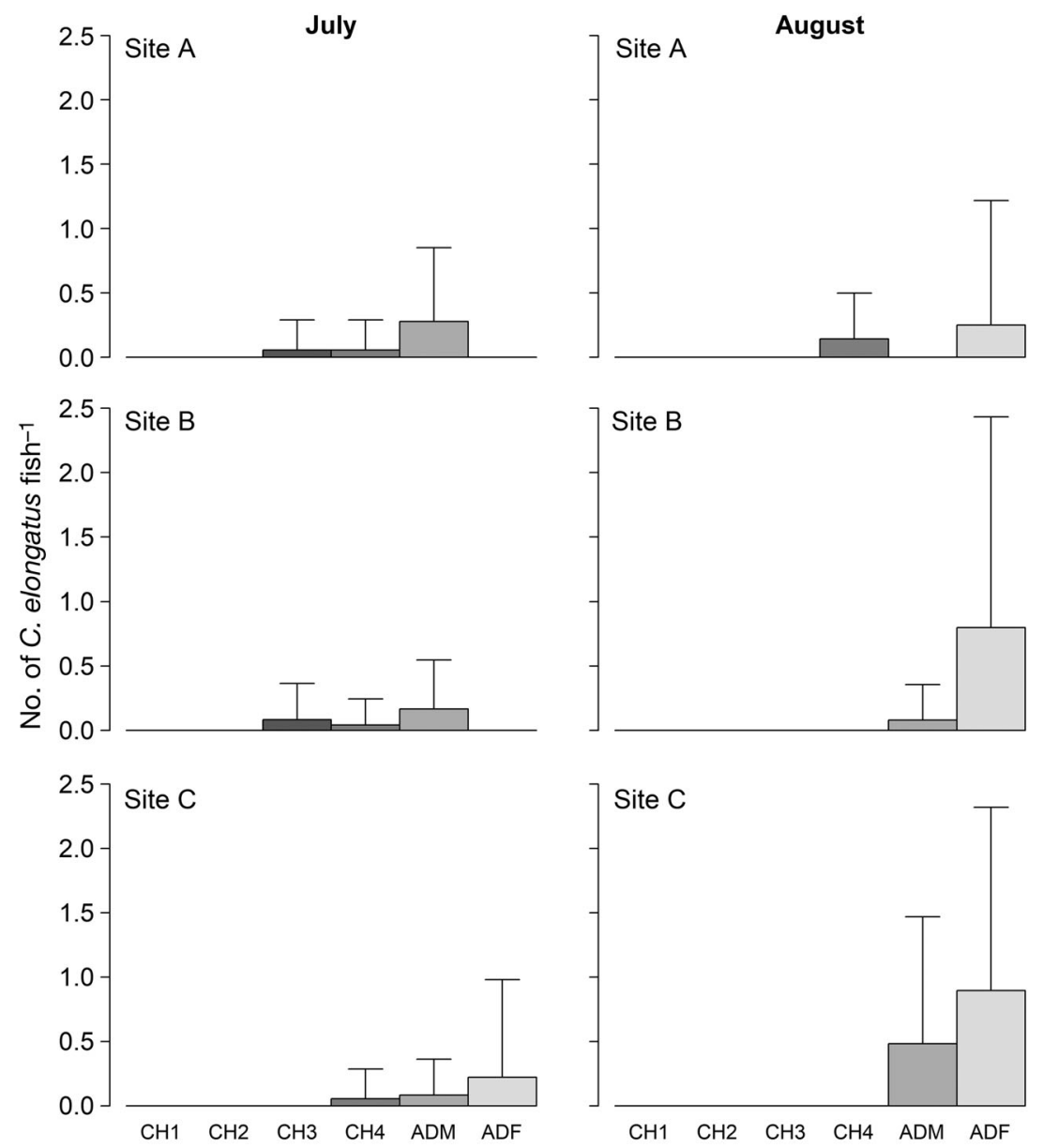

Fig. 4. Mean \pm SD abundance (see Table 1) of Caligus elongatus from the gillnet study. Data are visualized separately for all 3 sampling sites and both sampling months. See Fig. 3 for abbreviations

No significant differences in sea lice abundances (both salmonid size classes pooled) existed among sites in either July (Kruskal-Wallis test, $\chi^{2}=2.460$, $\mathrm{p}=0.29)$ or August $\left(\chi^{2}=4.721, \mathrm{p}=0.094\right)$. Likewise, there were no differences among sites in lice abundances when salmonid size groups were analyzed separately, either for July (body length $<25 \mathrm{~cm}, \chi^{2}=$ 1.479, $\mathrm{p}=0.477$; body length $\geq 25 \mathrm{~cm}, \chi^{2}=0.236, \mathrm{p}=$ 0.889 ) or August (body length $<25 \mathrm{~cm}, \chi^{2}=3.024, \mathrm{p}=$ 0.221 ; body length $\geq 25 \mathrm{~cm}, \chi^{2}=1.698, \mathrm{p}=0.428$ ). When only taking $L$. salmonis into consideration, there were no significant differences in abundance among the sample sites in either July $\left(\chi^{2}=4.831, \mathrm{p}=\right.$ 0.089 ) or August $\left(\chi^{2}=5.802, \mathrm{p}=0.055\right)$. A similar comparison for $C$. elongatus showed no significant difference in abundance among sites in July $\left(\chi^{2}=\right.$ $0.259, \mathrm{p}=0.088$ ), although there was a marginally significant difference in August $\left(\chi^{2}=6.311, \mathrm{p}=\right.$ 0.043). Lice abundance on smaller fish (body length < $25 \mathrm{~cm}$ ) was greater than that on larger fish (body length $\geq 25 \mathrm{~cm}$ ) in July, but the difference was only marginally significant (Wilcoxon test, $W=790.5, \mathrm{p}=$ 0.035 ), and no significant difference was found in August $(W=524.5, \mathrm{p}=$ $0.774)$.

\subsection{Sentinel cage sampling}

Mortality of fish in sentinel cages was observed at all sites, possibly due to harsh weather conditions in the sea. Site $C_{\text {, }}$ which was the most exposed location to weather, had the highest average mortality rate. Of the 27 fish placed in each cage at the beginning of the $3 \mathrm{wk}$, the mortality rate varied. July had the highest mortality (82\% of individuals), followed by September ( $57 \%$ ) and then August (41\%). Of all fish from the sentinel cages analyzed for lice infestation, 731 lice were collected, of which the majority were of the species C. elongatus, comprising $97 \%$ of the total; only $1 \%$ were $L$. salmonis (all collected in August), and 2\% were unidentifiable. Only 1 fish had an abundance $>0.1$ lice $\mathrm{g}^{-1}$ fish weight, with 8 lice on a $78 \mathrm{~g}$ fish, while 28 fish had an abundance $>0.05$ lice $\mathrm{g}^{-1}$ fish weight.

Lice prevalence, abundance and intensity increased throughout the year (Tables 3-5). For the mean of all sites, lice prevalence ranged from 0.17 (July), through 0.66 (August) to 0.72 (September); lice abundance ranged from 0.23 (July), through 1.60 (August) to 1.71 (September); and lice intensity ranged from 1.38 (July) to 2.25 (August and September). The highest abundance of lice on the fish was found at Site A with a mean of 2.60 lice per fish occurring in September. Likewise, Site A had the highest inten-

Table 3. Mean prevalence (see Table 1) of lice from the sentinal cage study

\begin{tabular}{|lcccc|}
\hline Site & July & August & September & Total \\
\hline A & 0.15 & 0.83 & 0.89 & 0.62 \\
B & 0.29 & 0.82 & 0.62 & 0.58 \\
C & 0.00 & 0.42 & 0.48 & 0.30 \\
D & 0.22 & 0.58 & 0.88 & 0.56 \\
Total mean & 0.17 & 0.66 & 0.72 & 0.51 \\
\hline
\end{tabular}


Table 4. Mean \pm SD abundance (see Table 1) of lice from the sentinel cage study. There were 12, 12 and 8 Site A fish; 2, 17 and 9 Site B fish; 0, 9 and 14 Site C fish and 4, 21 and 13 Site D fish for July, August and September, respectively

\begin{tabular}{|lcccc|}
\hline Site & July & August & September & Total \\
\hline A & $0.21( \pm 0.29)$ & $2.56( \pm 4.25)$ & $2.60( \pm 3.54)$ & $1.79( \pm 2.11)$ \\
B & $0.43( \pm 0.62)$ & $2.14( \pm 3.34)$ & $1.32( \pm 1.78)$ & $1.30( \pm 1.37)$ \\
C & $0.00( \pm 0.00)$ & $0.63( \pm 0.94)$ & $0.67( \pm 0.68)$ & $0.43( \pm 0.49)$ \\
D & $0.28( \pm 0.33)$ & $1.06( \pm 1.45)$ & $2.23( \pm 2.65)$ & $1.19( \pm 1.16)$ \\
Total & $0.23( \pm 0.25)$ & $1.60( \pm 1.56)$ & $1.71( \pm 1.22)$ & $1.18( \pm 0.67)$ \\
\hline
\end{tabular}

Table 5. Mean \pm SD intensity (see Table 1) of lice infestation from the sentinel cage study. Numbers of fish as given in Table 4

\begin{tabular}{|lcccc|}
\hline Site & July & August & September & Total \\
\hline A & $1.38( \pm 0.27)$ & $3.09( \pm 3.47)$ & $2.94( \pm 3.00)$ & $2.47( \pm 1.73)$ \\
B & $1.50( \pm 0.50)$ & $2.60( \pm 2.85)$ & $2.13( \pm 1.12)$ & $2.08( \pm 1.22)$ \\
C & NA & $1.50( \pm 0.93)$ & $1.39( \pm 0.40)$ & $1.45( \pm 0.38)$ \\
D & $1.25( \pm 0.25)$ & $1.83( \pm 1.09)$ & $2.55( \pm 2.21)$ & $1.88( \pm 0.98)$ \\
Total & $1.38( \pm 0.14)$ & $2.25( \pm 1.27)$ & $2.25( \pm 1.15)$ & $1.97( \pm 0.56)$ \\
\hline
\end{tabular}

in July (Kruskal-Wallis test, $\chi^{2}=1.209, \mathrm{p}=$ $0.751)$; in contrast, lice abundances differed among sites in August $\left(\chi^{2}=45.076\right.$, $\mathrm{p}<0.001)$ and September $\left(\chi^{2}=43.901, \mathrm{p}<\right.$ $0.001)$.

\subsection{Other data}

Neither salinity nor temperature varied much between the 4 sites at the date of measurement. Mean salinity across all sites was $34.1 \%$, but varied according to depth. The lowest recorded salinity was $33.9 \%$ at a depth of $10 \mathrm{~cm}$ in Fossfjörður, and the highest recorded value was $34.2 \%$ at a depth of $1 \mathrm{~m}$ at Hjalli. Temperatures increased with depth at all sites, ranging from 7.6 to $8.2^{\circ} \mathrm{C}$ in Fossfjörður, from 7.8 to $7.9^{\circ} \mathrm{C}$ at Hjalli, from 7.4 to $8.2^{\circ} \mathrm{C}$ in Trostansfjörður and from 7.4 to $7.8^{\circ} \mathrm{C}$ in Haganes.

Of the 20 to 30 fish analyzed for each sity with 3.09 and 2.94 lice per infested fish occurring in August and September, respectively.

In July, infested fish were almost entirely infested with adult lice, rather than younger stages, at all sites (other than Site C where there was no infestation). In general, the frequency of adult lice stages decreased in August and September (17-65\%, according to site and month), accompanied by an increase in chalimus stages (Fig. 5).

The sea lice life stage with the highest mean abundance in July was adult female, while earlier stages (particularly chalimus 4) tended to dominate lice infestation in August and September. Site A and B had the highest mean abundances throughout all life stages, followed by Site D, with Site C having the lowest mean abundance of all 4 sites and no lice infestation in July (Fig. 6). There were significant differences in lice abundance between July and August (Wilcoxon test, $W=4520$, p < 0.001) and between July and September $(W=$ 3083, $\mathrm{p}<0.001$ ), but there was no significant difference between August and September $(W=22873, \mathrm{p}=$ $0.57)$. No significant difference in lice abundance among sites existed

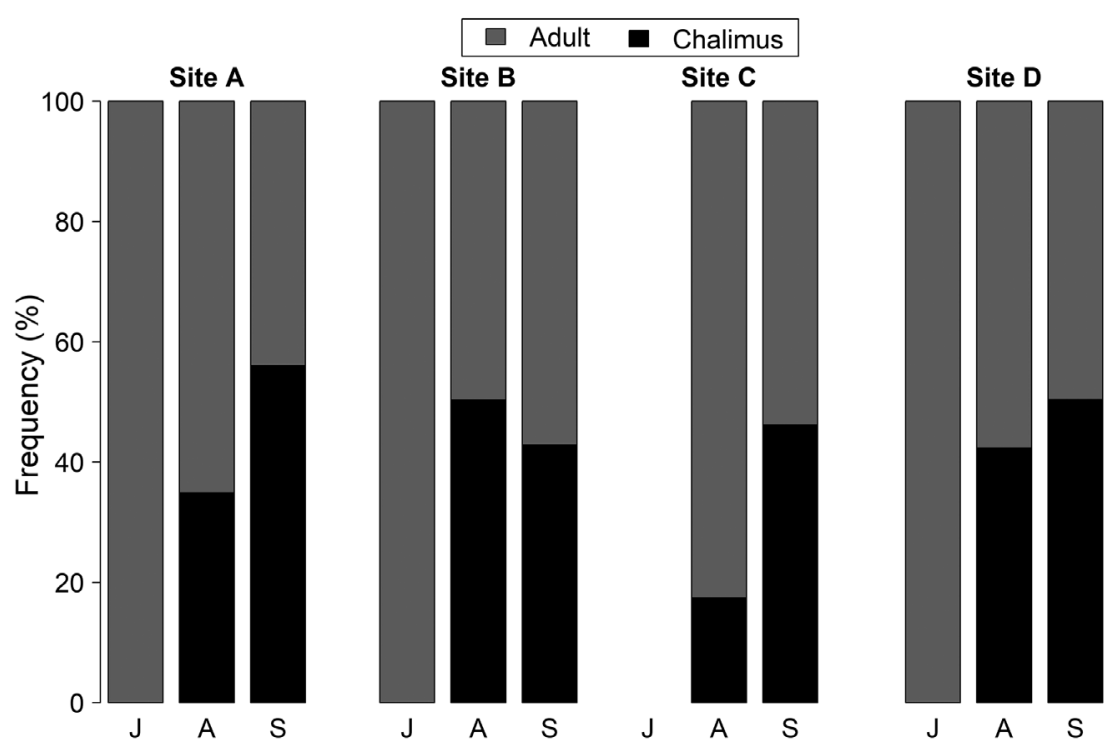

Fig. 5. Frequency of lice (adult and chalimus stages) per month and between sites for the sentinel cage study. The 3 columns show the 3 sampling months: July, August and September 

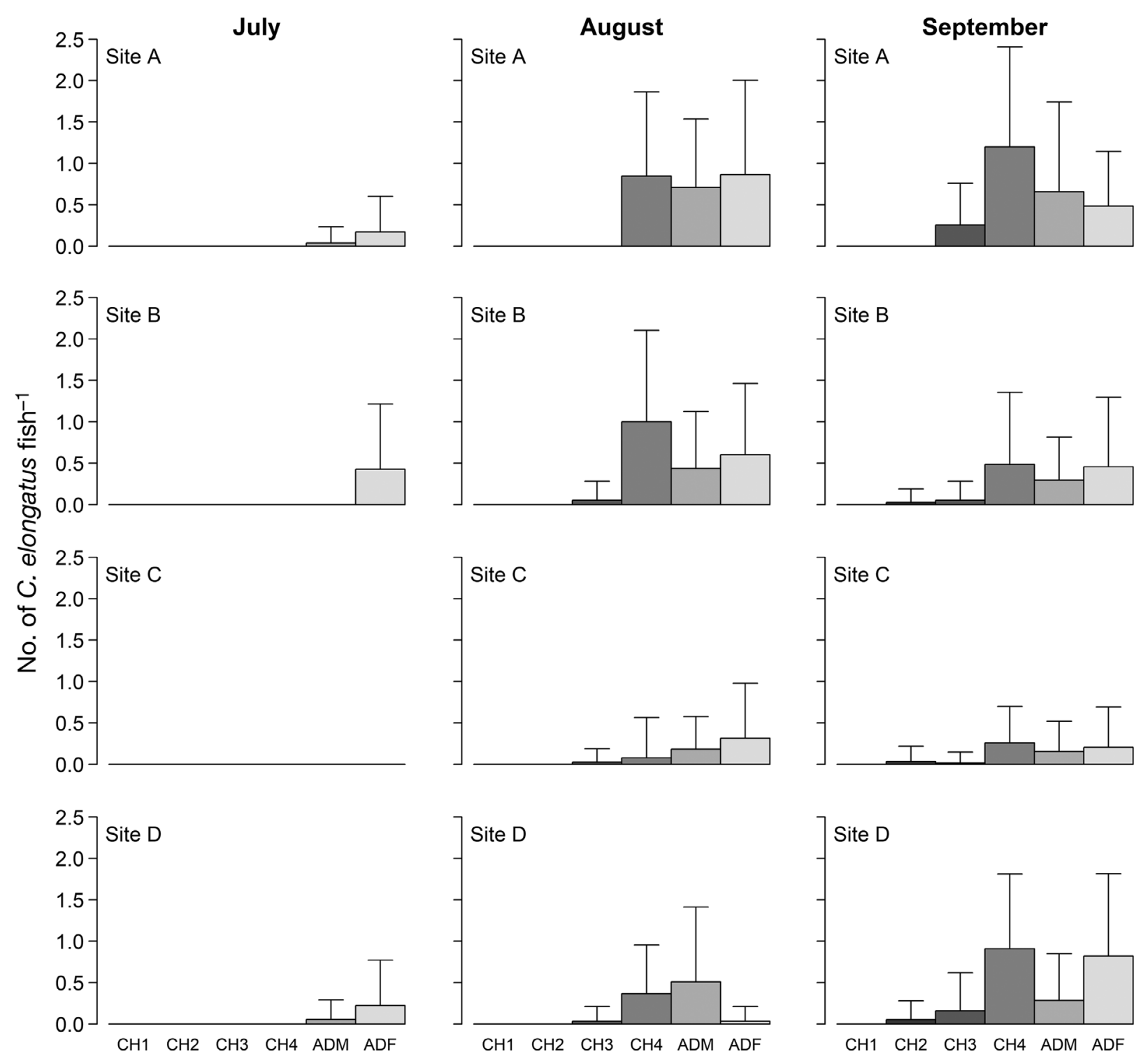

Fig. 6. Mean $\pm \mathrm{SD}$ abundance (see Table 1) of Caligus elongatus from the sentinel cage study. Only C. elongatus are summarized, as Lepeophtheirus salmonis only accounted for 7 of 731 lice. See Fig. 3 for abbreviations

\section{DISCUSSION}

This is the first in-depth study in Iceland on the sea lice infestation of wild salmonids in proximity to fish farms. We found that, on salmonids within the

Table 6. Number of sea lice collected at the 2 aquaculture farms from July to October and the percent of Caligus elongatus (C.e) and Lepeophtheirus salmonis (L.S) species identified

\begin{tabular}{|ccccccc|}
\hline & Jul & Aug & Sep & Oct & C.e $(\%)$ & L.s $(\%)$ \\
\hline Farm 1 & NA & 8 & 45 & NA & $98 \%$ & 2 \\
Farm 2 & 1 & 1 & 11 & 30 & $93 \%$ & 7 \\
\hline
\end{tabular}

fjord, lice infestation levels were low but increased throughout the year. Lice stage composition on hosts changed with an increasing preponderance of adult rather than sessile lice in late summer (August) in the gillnet study and an increasing proportion of chalimus rather than adult lice in late summer (August and September) in the sentinel cage study. Lice infestation in the sentinel cage study was dominated by Caligus elongatus (with very few Lepeophtheirus salmonis), and lice infestation was highest in sites closest to farms situated in the fjord.

Icelandic waters, especially in the northern part of the country, are colder than those in Scotland and southern Norway. It has been observed in several 
studies that sea lice hatching success substantially decreases in temperatures below $10^{\circ} \mathrm{C}$, leading to differences in development time (Boxaspen \& Næss 2000, Samsing et al. 2016). This is particularly important as, during this study, average sea surface temperatures changed quite quickly between June and the end of October. Sea surface temperatures were consistently below $10^{\circ} \mathrm{C}$ in July, but rose to $>10^{\circ} \mathrm{C}$ by August and September, staying above this until October when they dropped steadily to $\sim 8^{\circ} \mathrm{C}$.

The fastest rate of lice development will occur from late July to mid-August when sea temperatures peak. High infestation pressures on wild salmonids can thus be expected for the period after this peak in adult lice abundance. Most of the reported epizootics in Norway also occur at this time of the year (Taranger et al. 2015), adding credibility to the chosen timing of the study. Ideally, the temperature and salinity should have been measured at the 3 sampling locations at least once every month, but this was not possible due to limitations in the accessibility of the necessary gear. The reading from 24 October is still useful as it shows that sea surface temperatures were still moderately high at this time. Therefore, salmonids that stay in coastal marine waters, up to or even after this point, are likely exposed to potentially high numbers of lice extending into October. It has been shown that, especially in northern climates, salmonids can spend time in salt water during winter months. Fish have been shown to either undertake migration to sea or at times spend the whole winter at sea (Jensen \& Rikardsen 2012).

Several studies have shown that sea lice can not only have a direct lethal effect on the host fish but also have various sublethal effects (Finstad \& Bjørn 2011). It is thus difficult to estimate a threshold for when lice abundance on the host fish results in pathogenic effects, although multiple studies suggest the use of a level of 0.1 lice $\mathrm{g}^{-1}$ fish weight of the host as a value for this threshold (Fast et al. 2006, Finstad \& Bjørn 2011, Taranger et al. 2015). The wild salmonids sampled in the gillnet study had lice abundances mainly below this critical level of 0.1 lice $\mathrm{g}^{-1}$ fish weight. In total, there were 9 fish $(5.6 \%$ of the total sample) that exceeded this value and were thus possibly being negatively impacted by the attached lice. All of these were sea trout; 3 were caught in July and 6 in August. It can be suggested from these facts that there was no acute concern for the wild salmonid stocks in the sampled areas at this period. However, most fish caught were sea trout, meaning that the conclusion from this study only applies for this species directly.
Sea lice abundance in the sentinel cage study was substantially higher in both August and September than in July, when all sites were considered. Only adult sea lice were found in July, which may be representative of the longer generation time needed, resulting in prolonged sexual development and inability of the lice to complete a full cycle due to the lower sea surface temperatures (Johnson \& Albright 1991a,b). The fact that only adult sea lice were found means that lice attached immediately following placement in the sentinel cages at sea and only developed into the adult stage during the $21 \mathrm{~d}$ sample period, as no sea lice life stages, other than adult, were collected.

These results may also be, in part, skewed by the death rates of sentinel cage Atlantic salmon smolts, as fish died during the first sampling period. Similar sentinel cage studies conducted in Scotland have also shown mortality issues: for example, the study by Salama et al. (2013) involved 1 in 10 cages being lost and 1 in 10 cages having experienced complete mortality, attributed to severe winds. Jackson et al. (2012) has attempted to assess the mortality observed in various types of sentinel cages, suggesting that it is not uncommon for death rates to be considered when using sentinel cage sampling of sea lice abundance in the water column.

The greater abundance of sea lice found at Site A and B than at Site C in the sentinel cage study is of particular interest as Site A and B were located closest to the 2 farms. This corresponds to several other studies done in Ireland, Scotland and Norway that suggest the increase in concentration of hosts from salmon farms has increased lice abundance in the waters adjacent to these farms (Tully et al. 1999, Heuch \& Mo 2001, Butler 2002, Gargan et al. 2003, Serra-Llinares et al. 2014, 2016, Shephard et al. 2016). However, the suggestion of a correlation between results of a high abundance nearest the salmon farms is challenged by the fact that the second-highest average abundance, within sites for the 3 sampling months, was observed at Site $\mathrm{D}$, located the furthest away from the aquaculture sites, with an abundance of 2.2 lice, and that site also had the third overall highest average abundance with a value of 1.2 lice.

The low intensities found on lice in the farms may reflect the time in the production cycle when they were sampled. It has been suggested that farms are only substantial sources of sea lice abundance at certain times in the production cycle (Penston et al. 2008), with the beginning of the production experiencing relatively minimal sea lice abundance because fish are stocked free of sea lice infestation, and 
with an increase in abundance occurring in the second year of the production cycle (see Revie et al. 2002, Lees et al. 2008). This can also be observed in the sea lice count made by farm operators at the 2 farms located in the fjord from the first year of the $2 \mathrm{yr}$ production cycle, where lice abundance on the farms had not reached a level of concern. Farm 1 had only 8 lice (on 36 sampled fish) recorded in August and 45 lice (on 24 sampled fish) recorded in September. Farm 2 had only 1 sea lice (on 25 sampled fish) recorded in July, 1 sea lice (on 17 sampled fish) in August, 11 sea lice (on 20 sampled fish) in September, and 30 lice (on 20 sampled fish) in October.

A final point of discussion is the very high proportion of C. elongatus compared to L. salmonis found on fish in the sentinel cages. C. elongatus accounted for $97 \%$ in the fish sampled from the sentinel cages. This could be part of a normal succession as infestations on salmonid farms typically begin with C. elongatus and are later replaced by L. salmonis, which then will continue to be the dominant species observed (McKenzie et al. 2004), and by the fact that the majority of lice species found in Farms 1 and 2 were of Caligus origin. Another potential factor is wild fish within the area as a potential source for sea lice transmission.

Due to the natural presence of sea lice in the water column, a certain level of infestation will occur in wild salmonids, explaining the prevalence, abundances and intensities found in this study. The values for the latter are also in accordance with reports from areas without any aquaculture activity in Norway (Rikardsen 2004), leading to the inference that the farming along the Icelandic coastline has not had a measurable influence on lice intensities in wild populations. Further research is needed to collect more data and address this further, especially when farming intensity in this and other fjord systems along the Icelandic coastline are increasing.

Implementing a coordinated management system for coastal salmon farms - in Arnarfjörður specifically and Iceland more broadly-is key to avoiding reaching sea lice levels that can trigger an infestation outbreak. Such management systems have been implemented in other countries, although the practices have varied. In Scotland, farm management areas, (FMAs) which involve farm management practices adhering to a code of good practice within the FMAs (Murray \& Gubbins 2016), have proven to be a successful management tool for sustainable environmental development. Disease MAs have also been implemented in Scotland, important for the management of diseases that are of concern when dispersed
(Salama et al. 2013). In Norway, a newly developed 'traffic light system' for sustainable fish farming has been implemented to ensure coordinated management of fish farming (Vollset et al. 2018).

When considering future research, the methods of sentinel cage and gillnet sampling conducted in our study are of high importance. This sampling should be performed simultaneously throughout and across years, preferably from the first production cycle throughout the life of the aquaculture farm to provide information for more effective development of farm management. Our study, for example, has provided baseline information for the abundance of sea lice within areas of Arnarfjörður before salmonid production has substantially developed, which may be used to set baseline levels in this fjord. Consideration should also be given to studying one or multiple sites without any aquaculture impact to have baseline data for control sites located outside the proximity of any existing aquaculture.

\section{CONCLUSIONS}

This is the first detailed study on levels of sea lice infestation of wild and farmed salmonids in a fjord system in Iceland and gives a baseline for the assessment of sea lice abundance within Arnarfjörður, in the Westfjords of Iceland. The prevalence of sea lice and intensity of infestation was low in this study, especially for L. salmonis, and the intensities of infestation were below the estimated thresholds for negative impacts of lice on their hosts. However, the 2 study sites observed to have the highest abundance of sea lice were located closest to the aquaculture farms. If production were to remain at the level occurring during this research study, and the existing farms were to maintain a low number of sea lice on the farmed fish, the fjord may not be faced with the threat of sea lice epidemics; it is suggested that lowproduction areas have not been observed to experience high sea lice abundance and do not provide the opportunity for epidemics to develop (Costello, 2009b). However, if salmonid aquaculture develops and production is increased within the fjord, the risk of sea lice epidemics will increase along with the need for this type of environmental monitoring and coastal zone management.

Acknowledgements. This work was carried out with financial support from 2 aquaculture companies in Iceland, as well as financial contributions from the Norwegian Institute for Nature Research (NINA). The project was further sup- 
ported by Jón Örn Pálsson, at the time the Fjardalax Research and Development Manager, senior engineer Marius Berg at NINA, and Dagny Arnarsdottir, Kristín Ósk Jónasdóttir and Peter Weiss, at the time with the University Centre of the Westfjords. Both the Icelandic Environmental Agency and Health Authority as well as local landowners within Arnarfjörður gave authorization to perform this research.

\section{LITERATURE CITED}

Bjørn PA, Finstad B, Kristoffersen R (2001) Salmon lice infection of wild sea trout and Arctic char in marine and freshwaters: the effects of salmon farms. Aquacult Res 32: 947-962

Bjørn PA, Finstad B, Kristoffersen R, McKinley RS, Rikardsen AH (2007) Differences in risks and consequences of salmon louse, Lepeophtheirus salmonis (Kroyer), infestation on sympatric populations of Atlantic salmon, brown trout, and Arctic charr within northern fjords. ICES J Mar Sci 64:386-393

Bjørn PA, Sivertsgård R, Finstad B, Nilsen R, Serra-Llinares RM, Kristoffersen R (2011) Area protection may reduce salmon louse infection risk to wild salmonids. Aquacult Environ Interact 1:233-244

Boxaspen K (2006) A review of the biology and genetics of sea lice. ICES J Mar Sci 63:1304-1316

Boxaspen K, Næss T (2000) Development of eggs and the planktonic stages of salmon lice (Lepeophtheirus salmonis) at low temperatures. Contrib Zool 69:51-55

* Brooker AJ, Skern-Mauritzen R, Bron JE (2018) Production, mortality, and infectivity of planktonic larval sea lice, Lepeophtheirus salmonis (Krøyer, 1837): current knowledge and implications for epidemiological modelling. ICES J Mar Sci 75:1214-1234

Bush AO, Lafferty KD, Lotz JM, Shostak AW (1997) Parasitology meets ecology on its own terms: Margolis et al. revisited. J Parasitol 83:575-583

Butler JRA (2002) Wild salmonids and sea louse infestations on the west coast of Scotland: sources of infection and implications for the management of marine salmon farms. Pest Manag Sci 58:595-608

Butler JRA, Watt J, Mills D (2003) Assessing and managing the impacts of marine salmon farms on wild Atlantic salmon in western Scotland: identifying priority rivers for conservation. In: Mills D (ed) Salmon at the edge. Blackwell Science, Oxford, p 93-118

Costello MJ (1993) Review of methods to control sea lice (Caligidae: Crustacea) infestations on salmon (Salmo salar) farms. In: Boxhall GA, Defaye D (eds) Pathogens of wild and farmed fish: sea lice. Ellis Horwood, p 219-252

Costello MJ (2006) Ecology of sea lice parasitic on farmed and wild fish. Trends Parasitol 22:475-483

* Costello MJ (2009a) How sea lice from salmon farms may cause wild salmonid declines in Europe and North America and be a threat to fishes elsewhere. Proc R Soc B 276: 3385-3394

Costello MJ (2009b) The global economic cost of sea lice to the salmonid farming industry. J Fish Dis 32:115-118

Fast MD, Ross NW, Muise DM, Johnson SC (2006) Differential gene expression in Atlantic salmon Infected with Lepeophtheirus salmonis. J Aquat Anim Health 18: 116-127

Finstad B, Bjørn PA (2011) Present status and implications of salmon lice on wild salmonids in Norwegian coastal zones. In: Jones S, Bemish R (eds) Salmon lice: an integrated approach to understanding parasite abundance and distribution. Wiley-Blackwell, Oxford, p 281-305

Finstad B, Bjørn PA, Todd CD, Whoriskey F, Gargan PG, Forde G, Revie CW (2011) The effect of sea lice on Atlantic salmon and other salmonid species. In: Aas $\varnothing$, Einum S, Klemetsen A, Skurdal J (eds) Atlantic salmon ecology. Wiley-Blackwell, Oxford, p 253-276

Gargan PG, Tully O, Poole WR (2003). The relationship between sea lice infestation, sea lice production and sea trout survival in Ireland, 1992-2001. In: Mills D (ed) Salmon at the edge. Blackwell Science, Oxford, p 119-135

Gargan PG, Kelly FL, Shephard S, Whelan KF (2016) Temporal variation in sea trout Salmo trutta life history traits in the Erriff River, western Ireland. Aquacult Environ Interact 8:675-689

*Hamre LA, Eichner C, Caipang CMA, Dalvin ST and others (2013) The salmon louse Lepeophtheirus salmonis (Copepoda: Caligidae) life cycle has only two chalimus stages. PLOS ONE 8:e73539

* Heuch PA, Mo TA (2001) A model of salmon louse production in Norway: effects of increasing salmon production and public management measures. Dis Aquat Org 45: 145-152

Jackson D, O'Donohoe P, Kane F, Kelly S, Dermott TM, Drumm A, Nolan G (2012) Result of an epidemiological study of sea lice infestation in South Connemara, West of Ireland. Aquaculture 364-365:118-123

Jensen JLA, Rikardsen AH (2012) Archival tags reveal that Arctic charr Salvelinus alpinus and brown trout Salmo trutta can use estuarine and marine waters during winter. J Fish Biol 81:735-749

Johnsen GH, Tveranger B (2011) Arnarfjörður in Iceland. Environmental effects of aquaculture with focus on northern shrimp. Rådgivende Biologer, Bergen

Johnsen IA, Fiksen Ø, Sandvik AD, Asplin L (2014) Vertical salmon lice behaviour as a response to environmental conditions and its influence on regional dispersion in a fjord system. Aquacult Environ Interact 5:127-141

Johnson SC, Albright LJ (1991a) Development, growth, and survival of Lepeophtheirus salmonis (Copepoda: Caligidae) under laboratory conditions. J Mar Biol Assoc UK 71:425-436

Johnson SC, Albright LJ (1991b) The developmental stages of Lepeophtheirus salmonis (Krøyer, 1837) (Copepoda: Caligidae). Can J Zool 69:929-950

Klemetsen A, Amundsen PA, Dempson JB, Jonsson B, Jonsson N, O'Connell MF, Mortensen E (2003) Atlantic salmon Salmo salar L., brown trout Salmo trutta L. and Arctic charr Salvelinus alpinus (L.): a review of aspects of their life histories. Ecol Freshwat Fish 12:1-59

Kristinsson JB (1992) Aquaculture in Iceland - history and present status. Icel Agric Sci 6:5-8

Lees F, Gettinby G, Revie CW (2008) Changes in epidemiological patterns of sea lice infestation on farmed Atlantic salmon, Salmo salar L., in Scotland between 1996 and 2006. J Fish Dis 31:259-268

McKenzie E, Gettinby G, McCart K, Revie CW (2004) Timeseries models of sea lice Caligus elongatus (Nordmann) abundance on Atlantic salmon Salmo salar L. in Loch Sunart, Scotland. Aquacult Res 35:764-772

* Murray AG, Gubbins M (2016) Spatial management measures for disease mitigation as practiced in Scottish aquaculture. Mar Policy 70:93-100 
Paisley LG, Ariel E, Lyngstad T, Jónsson G, Vennerström P, Hellström A, Østergaard P (2010) An overview of aquaculture in the Nordic countries. J World Aquacult Soc 41: $1-17$

Penston MJ, Millar CP, Zuur A, Davies IM (2008) Spatial and temporal distribution of Lepeophtheirus salmonis (Krøyer) larvae in a sea loch containing Atlantic salmon, Salmo salar L., farms on the north-west coast of Scotland. J Fish Dis 31:361-371

Piasecki W, MacKinnon B (1995) Life cycle of a sea louse, Caligus elongatus von Normann, 1832 (Copepoda, Siphonostomatoida, Caligidae). Can J Zool 73:74-82

Pike AW, Wadsworth SL (2000) Sealice on salmonids: their biology and control. Adv Parasitol 44:233-337

Revie CW, Gettinby G, Treasurer JW, Rae GH, Clark N (2002) Temporal, environmental and management factors influencing the epidemiological patterns of sea lice (Lepeophtheirus salmonis) infestations on farmed Atlantic salmon (Salmo salar) in Scotland. Pest Manag Sci 58: 576-584

Rikardsen AH (2004) Seasonal occurrence of sea lice Lepeophtheirus salmonis on sea trout in two north Norwegian fjords. J Fish Biol 65:711-722

Rosten TW (2013) Perspectives for sustainable development of Nordic aquaculture: the Paban report. Nordic Council of Ministers, Copenhagen

Salama NKG, Collins CM, Fraser JG, Dunn J, Pert CC, Murray AG, Rabe B (2013) Development and assessment of a biophysical dispersal model for sea lice. J Fish Dis 36: 323-337

Samsing F, Oppedal F, Dalvin S, Johnsen I, Vågseth T, Dempster T (2016) Salmon lice (Lepeophtheirus salmonis) development times, body size, and reproductive outputs follow universal models of temperature dependence. Can J Fish Aquat Sci 73:1841-1851

Schram TA (1993) Supplementary descriptions of the developmental stages of Lepeophtheirus salmonis (Krøyer, 1837) (Copepoda: Caligidae). In: Boxhall GA, Defaye D

Editorial responsibility: Tim Dempster,

Melbourne, Victoria, Australia (eds) Pathogens of wild and farmed fish: sea lice. Ellis Horwood, Chichester, p 30-47

Schram TA (2004) Practical identification of pelagic sea lice larvae. J Mar Biol Assoc UK 84:103-110

Serra-Llinares RM, Bjørn PA, Finstad B, Nilsen R, Harbitz A, Berg M, Asplin L (2014) Salmon lice infection on wild salmonids in marine protected areas: an evaluation of the Norwegian 'National Salmon Fjords'. Aquacult Environ Interact 5:1-16

Serra-Llinares RM, Bjørn PA, Finstad B, Nilsen R, Asplin L (2016) Nearby farms are a source of lice for wild salmonids: a reply to Jansen et al. (2016). Aquacult Environ Interact 8:351-356

Shephard S, MacIntyre C, Gargan P (2016) Aquaculture and environmental drivers of salmon lice infestation and body condition in sea trout. Aquacult Environ Interact 8: $597-610$

Skilbrei OT, Finstad B, Urdal K, Bakke G, Kroglund F, Strand R (2013) Impact of early salmon louse, Lepeophtheirus salmonis infestation and differences in survival and marine growth of sea-ranched Atlantic salmon, Salmo salar L., smolts 1997-2009. J Fish Dis 36:249-260

Taranger GL, Karlsen Ø, Bannister RJ, Glover KA and others (2015) Risk assessment of the environmental impact of Norwegian Atlantic salmon farming. ICES J Mar Sci 72: 997-1021

Thorstad EB, Finstad B (2018) Impacts of salmon lice emanating from salmon farms on wild Atlantic salmon and sea trout. NINA Report 1449:1-22

* Tully O, Gargan P, Poole WR, Whelan KF (1999) Spatial and temporal variation in the infestation of sea trout (Salmo trutta L.) by the caligid copepod Lepeophtheirus salmonis (Krøyer) in relation to sources of infection in Ireland. Parasitology 119:41-51

*Vollset KW, Dohoo I, Karlsen Ø, Halttunen E and others (2018) Food for thought: disentangling the role of sea lice on the marine survival of Atlantic salmon. ICES J Mar Sci 75:50-60

Submitted: April 13, 2018; Accepted: February 4, 2019

Proofs received from author(s): April 7, 2019 